\section{Bij een jubileum}

Het 25-jarig bestaan van het Laboratorium der Nederlandse Apothekers heeft op I september jl. de nodige aandacht gekregen en terecht, want een dergelijk jubileum binnen de Nederlandse apothekersgemeenschap is belangrijk genoeg om een ogenblik bij stil te staan.

Maar belangrijker nog dan organisaties en instellingen zijn de mensen die daarin werken. En wanneer een van deze werkers op dezelfde datum zijn zilveren jubileum viert, is dat een reden te meer hieraan aandacht te besteden, dat is uniek.

ALEXANDER W.M. INDEMANS trad op I september r 956 in dienst van de KNMP als de eerste en op dat moment ook de enige apotheker-medewerker van het LNA. Hij stamde weliswaar uit een apothekersfamilie (vader en grootvader waren beide farmaceut en firmanten van de bekende groothandel uit 's-Hertogenbosch: Dr. Lamers en Dr. Indemans), maar hij had zich toch aan de Utrechtse universiteit laten inschrijven bij de faculteit Chemie. Niet dat de farmacie hem niet aantrok, neen, maar een familielid had hem de chemie sterk aanbevolen, zeggende dat er aan de apothekerij geen droog brood te verdienen was. Nu hoorde men omstreeks 1940 wel vaker dergelijke geluiden en ook nu zijn ze nog niet verstomd, maar gelukkig is de situatie steeds wel wat meegevallen, ook in dit opzicht.

$\mathrm{Na}$ een noodgedwongen onderbreking gedurende de oorlogsjaren, waarin de student INDEMANS in Hamburg te werk werd gesteld, werd in 1946 de studie in Utrecht hervat, maar nu wel in de ons meer vertrouwde subfaculteit der Farmacie. In betrekkelijk korte tijd wist INDEMANS het apothekersdiploma te behalen ( 9 april 1949) maar de farmaceutische wetenschap had hem inmiddels zo geboeid dat hij zijn leermeester Prof. J.A.c. VAN PINXTEREN niet kon verlaten en onder diens leiding een proefschrift bewerkte dat op 16 maart 1953 in het openbaar werd verdedigd. Deze dissertatie betrof een analytisch onderwerp, namelijk onderzoekingen over fluorescentie. Deze voorkeur voor analytische chemie, maar dan toegepast op farmaceutische grond- en hulpstoffen en preparaten, is INDEMANs steeds aan de dag blijven leggen.

$\mathrm{Na}$ enkele jaren in de eerder genoemde groothandel te hebben gewerkt, keerde INDEMANS Brabant de rug toe en vertrok weer naar Utrecht, waar het LNA zijn bakermat had, nl. in het privélaboratorium van VAN PINXTEREN. De LNA-staf werd gaandeweg uitgebreid en in 1968 verhuisde het LNA naar het KNMPcentrum te 's-Gravenhage. Parallel hiermee werd INDEMANS eerst hoofd van de Analytische Afdeling, daarna hoofd van het LNA en ten slotte directeur.

Zijn invloed op de werkzaamheden is zonder meer groot te noemen, geen wonder ook, omdat de hele organisatie, taakstelling en -uitvoering door INDE-

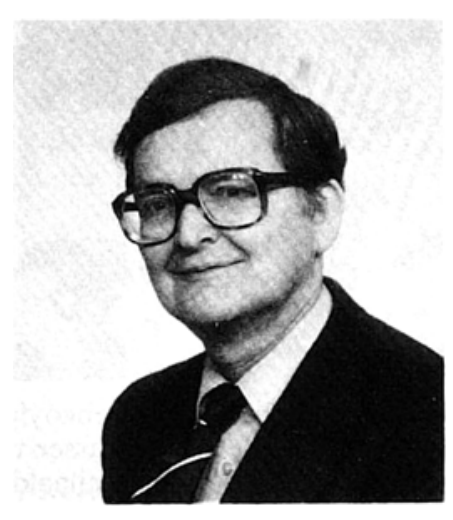

MANS in de aanvang met eigen handen moest worden opgebouwd. Zijn omgang met collega's en medewerkers is uitstekend en kenmerkend zou ik zijn bereidwilligheid en vriendelijkheid willen noemen. Toch, wanneer hij meent dat aan zijn belangen en in het bijzonder aan die van zijn medewerkers tekort wordt gedaan, slaat de vriendelijkheid om in heilige toorn en moet er heel wat worden geklaard voordat het LNA-zonnetje weer schijnt. De hechting van INDEMANS aan het LNA is sterk, hij vond er bovendien zijn bruid in de persoon van YVONNE FITSCH, met wie hij op 22 december 1973 in het huwelijk trad.

Vele publikaties van zijn hand, al of niet met medewerkers voorbereid, getuigen van de wetenschappelijke arbeid van INDEMANS. Dat zijn verdiensten ook door anderen worden geschat moge blijken uit zijn vele nevenfuncties, waarvan genoemd worden: buitengewoon hoogleraar in de farmaceutische chemie aan de Rijksuniversiteit te Utrecht; lid van de Nederlandse Farmacopeecommissie; lid van de Europese Farmacopeecommissie; lid van de sectie Officiële Laboratoria en Diensten voor Geneesmiddelencontrole van de Fédération Internationale Pharmaceutique; plv. lid van de Commissie van Voorbereiding PAO-Farmacie.

Veel zou nog te zeggen zijn van INDEMANS als directeur, als teamgenoot, als collega en als medemens, juist bij dit zilveren ambtsjubileum. Veel is al gezegd op de achter ons liggende symposiumdag, veel zal ook ongezegd blijven, want men kan niet alles - hoe goed ook bedoeld - aan de openbaarheid prijsgeven.

Met een ding wil ik daarom afsluiten en dat is de wens dat het INDEMANS gegeven mag zijn in de vijf jaren die hem nog van de pensioengerechtigde leeftijd scheiden, op dezelfde voortvarende, sympathieke en wetenschappelijk én praktisch verantwoorde wijze over het LNA de scepter te blijven zwaaien. De KNMP is hem daarvoor nu reeds veel dank verschuldigd.

H.A. SLOOT 